\title{
Nitrogen Fertilizer and Seeding Rate Influence on Grain and Forage Yield of Dual-Purpose Barley
}

\author{
S. Hajighasemi, R. Keshavarz-Afshar,* and M. R. Chaichi
}

\begin{abstract}
Clipping fall-sown cereals provides a good source of high-quality forage during late winter. Farmers usually use more inputs, including fertilizers and seed, in dual-purpose systems compared with grain-only systems. A 2-yr field study was conducted in Karaj, Iran, to evaluate the effects of nitrogen $(\mathrm{N})$ rates $(0,50$, $\left.100,150 \mathrm{~kg} \mathrm{~N} \mathrm{ha}^{-1}\right)$ and seeding rates $\left(400,600,800\right.$ seed $\left.^{-2}\right)$ on forage and grain yields of two barley (Hordeum vulgare L.) cultivars (Fasih and CB 744) in grain-only and dual-purpose systems. Fasih and CB 744 grain yields in the grain-only system were 2996 and $3250 \mathrm{~kg} \mathrm{ha}^{-1}$, respectively (averaged over experimental treatments). Forage removal in the dual-purpose system resulted in $25 \%$ grain yield penalty. Despite the lower grain yield, the economic return of the dual-purpose system was considerably greater due to the high price of forage during late winter in the region. Grain yield response to $\mathrm{N}$ was linear in the grain-only system, but the trend was not significant in the dual-purpose system. In both production systems, grain yield response to seeding rate was quadratic, and the highest yields of both cultivars (2534 and $3192 \mathrm{~kg} \mathrm{ha}^{-1}$ for Fasih and CB 744, respectively) were obtained from $600 \mathrm{seed}^{-2}$. In both production systems, 600 seed $\mathrm{m}^{-2}$ and $100 \mathrm{~kg} \mathrm{~N} \mathrm{ha}^{-1}$ were optimum for grain and forage production. Our results showed considerably higher revenue in the dual-purpose system compared with the grain-only system in this region. Moreover, no additional inputs of $\mathrm{N}$ and seed are required for dual-purpose barley than those usually used in a grain-only system.
\end{abstract}

\section{Core Ideas}

- Dual-purpose barley yielded 25\% less grain than that in grainonly system.

- Despite a lower grain yield, economic return of dual-purpose barley was considerably greater.

- In both production systems, 600 seed m${ }^{-2}$ and $100 \mathrm{~kg} \mathrm{~N} \mathrm{ha}^{-1}$ were optimum for grain and forage production.

- No additional $\mathrm{N}$ and seed are required for dual-purpose barley than those usually used in grain-only system.

Published in Agron. J. 108:1486-1494 (2016)

doi:10.2134/agronj2015.0447

Received 14 Sept. 2015

Accepted 28 Mar. 2016

Available freely online through the author-supported open access option

Copyright (C) 2016 American Society of Agronomy

5585 Guilford Road, Madison, WI 53711 USA

This is an open access article distributed under the CC BY-NC-ND

license (http://creativecommons.org/licenses/by-nc-nd/4.0/)
$\mathrm{F}$ EED SHORTAGES during late winter and early spring are among the major constraints of livestock production in many areas (Afshar et al., 2012, 2014; Sadeghpour et al., 2013; Tian et al., 2012). Clipping and/or grazing fall-sown cereals, mostly wheat (Triticum aestivum L.) and barley, provides a good source of high-quality forage in the feed gap period in many countries, such as the United States, Canada, Argentina, Morocco, Pakistan, Syria, Uruguay, Australia, and Mediterranean countries (Harrison et al., 2012). Variable results have been reported about the impact of forage removal on the grain yield of cereals. In some cases, yield penalties have been reported (Epplin et al., 2000; Khalil et al., 2011). Virgona et al. (2006) studied the effect of grazing by sheep during the late vegetative and early reproductive phases on wheat crops in two experiments. In the first experiment, grazing 40 dry-sheep equivalents ha ${ }^{-1}$ for $19 \mathrm{~d}$ increased grain yield from 2300 to $2880 \mathrm{~kg} \mathrm{ha}^{-1}$. In their second experiment under more favorable environmental conditions, the effects of grazing varied from no yield reduction with $15 \mathrm{~d}$ of grazing to a $33 \%$ reduction with $51 \mathrm{~d}$ of grazing. This reduction has been attributed mainly to the removal of the crop growing points due to unsuitable time of defoliation and to a smaller photosynthetic surface after forage removal (Virgona et al., 2006). Grain yield improvement after forage removal has also been reported. Under favorable conditions (mainly sufficient water availability), grain yield increment due to defoliation has been attributed to a lower incidence of lodging, moderation of foliar disease, and rapid recovery of leaf area; in stressed conditions, it has been related to lower transpiration (conservation of soil moisture), delayed phonology, and greater remobilization of stem reserves to grains (Harrison et al., 2012).

Some researchers have reported on the economic advantages of dual-purpose systems compared with grain-only systems (Arzadun et al., 2003, 2006; Decker et al., 2009). The dual-purpose system would be feasible if the forage value obtained is greater than any grain yield penalty from grazing/clipping. The objective could be achieved through enhancing early growth via genotype selection and/or optimization of crop management practices. Some aspects of crop management and their influences on the success of dualpurpose systems have been extensively investigated. For instance, it is well understood that dual-purpose cereals should be sown earlier

S. Hajighasemi and M.R. Chaichi, Dep. of Agronomy and Plants Breeding, College of Agriculture and Natural Resources, Univ. of Tehran, Karaj, Iran; R. Keshavarz-Afshar, Eastern Agric. Res. Center, Montana State Univ., Sidney, MT 59270. *Corresponding author (rezakeshavarz@montana.edu).

Abbreviations: ADF, acid detergent fiber; $\mathrm{CB}$, cultivar CB 744; $\mathrm{CP}$, crude protein; DMD, dry matter digestibility; FA, cultivar Fasih; GS, Zadoks growth stage; HI, harvest index; NIR, near-infrared spectroscopy. 


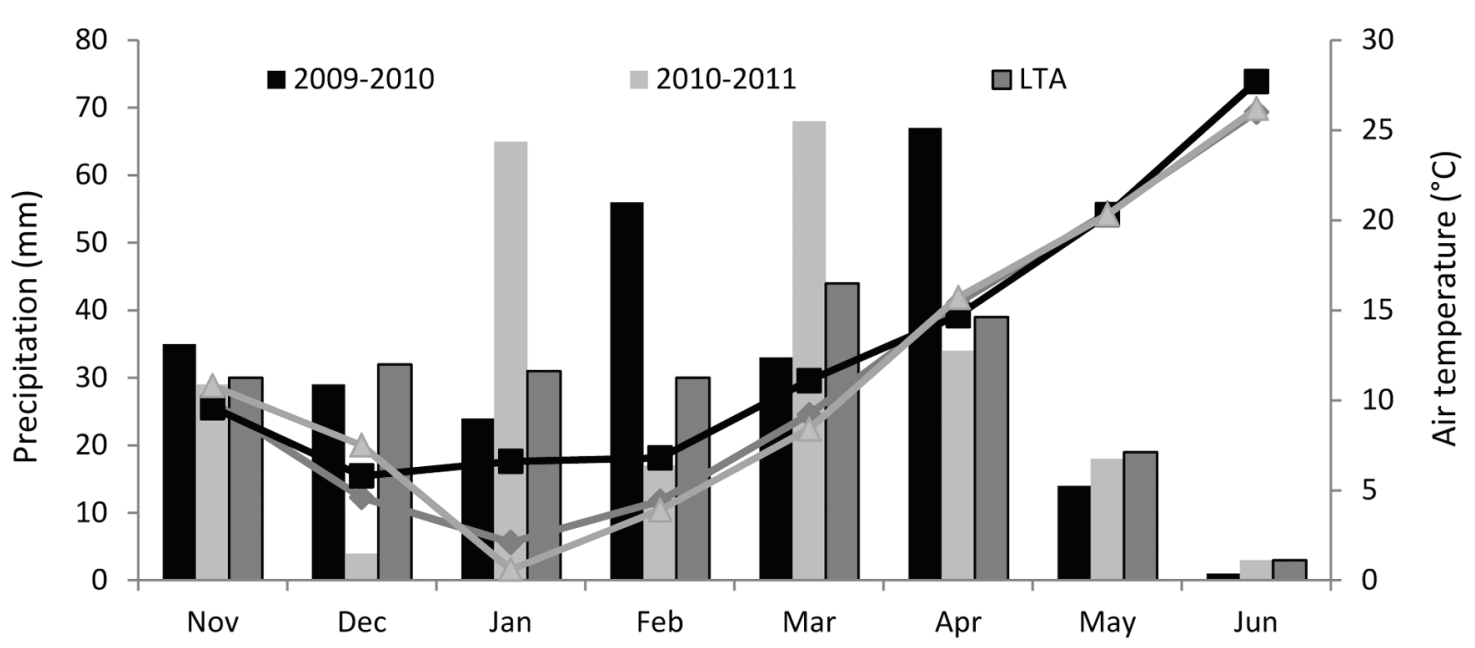

Fig. I. Monthly precipitation and average air temperature during the study and long-term (30-yr) average (LTA) at Karaj, Iran.

(when possible) than grain-only cereals and must be cut or grazed before the development of the first hollow stem or Zadoks growth stage (GS) 30 (Hossain et al., 2003). Nevertheless, limited information is available regarding the impacts of other crop management practices (e.g., fertilization and seeding rate) on the success of dual-purpose systems.

Defoliation removes nitrogen $(\mathrm{N})$ accumulated in plant aerial parts. It has been found that $\mathrm{N}$ availability plays an important role in crop regrowth after defoliation (Pandey, 2005; Tian et al., 2012). Using supplementary $\mathrm{N}$ fertilizer after forage removal, therefore, is a common practice in dual-purpose systems in many areas (Pandey, 2005; Tian et al., 2012). Sij et al. (2011) found a linear increase in forage production of wheat with increasing preplant $\mathrm{N}$ application. In their study, wheat grain yield increased as $\mathrm{N}$ rate increased. Tian et al. (2012) evaluated the effect of $\mathrm{N}$ topdressing rates $\left(0,60\right.$, and $\left.120 \mathrm{~kg} \mathrm{~N} \mathrm{ha}^{-1}\right)$ on grain yield recovery of wheat after forage removal. They reported no significant effect of $\mathrm{N}$ topdressing rate on grain yield of wheat. The effect of $\mathrm{N}$ fertilization on barley regrowth after defoliation has not been extensively investigated. Optimization of $\mathrm{N}$ use will result in enhanced $\mathrm{N}$ use efficiency, which is economically viable and environmentally sound (Ladha et al., 2005).

Seeding rate is another factor playing an important role in the success of dual-purpose systems (Hadjichristodoulou, 1991). Hadjichristodoulou (1991) suggested that a higher seeding rate can increase forage yield and stabilize grain yield of cereals in dual-purpose systems. In the southern Great Plains of the United States, wheat intended for dual-purpose management is sown at 1.5 to 2 times greater seeding density than what was used in grain-only systems (Edwards et al., 2011). Khalil et al. (2011) reported that a seeding rate of $150 \mathrm{~kg} \mathrm{ha}^{-1}$ along with $160 \mathrm{~kg} \mathrm{~N} \mathrm{ha}^{-1}$ produced the maximum forage dry matter and biological yield of wheat. In their study, however, grain yield was higher when $100 \mathrm{~kg} \mathrm{seed} \mathrm{ha}^{-1}$ plus $120 \mathrm{~kg} \mathrm{~N} \mathrm{ha}^{-1}$ was used. Pandey (2005) reported 14.5\% lower grain yield of wheat in a dual-purpose system compared with a grain-only system when no external $\mathrm{N}$ was applied. Pandey found no yield penalty in a dual-purpose system when $30 \mathrm{~kg} \mathrm{~N} \mathrm{ha}^{-1}$ alone or in combination with extra $25 \mathrm{~kg}$ seed ha ${ }^{-1}$ was applied. The effect of seeding rate on barley forage and grain yield and its interaction with $\mathrm{N}$ fertilization has not been evaluated extensively. Optimization of the seeding rate is important because the cost of seed is increasing worldwide.
The objective of this study was to evaluate the agronomic and economic performance of two barley cultivars in a dual-purpose system in Karaj, Iran. We also studied the impacts of N fertilization and seeding rate on the success of barley in grain-only and dual-purpose systems.

\section{MATERIALS AND METHODS}

\section{Site Description}

A 2-yr field experiment (2009-2010 and 2010-2011) was conducted at the Research Farm of the College of Agriculture and Natural Resources, University of Tehran, Karaj, Iran $\left(35^{\circ} 56^{\prime}\right.$ $\mathrm{N}, 50^{\circ} 58^{\prime} \mathrm{E}$ ). The location is characterized as semiarid, with long-term average annual precipitation of $262 \mathrm{~mm}$. The average monthly air temperature and monthly accumulative rainfall during the study and long-term average (30-yr) are presented in Fig. 1. The soil type of this site is a Typic Haplocambid in the USDA classification, clay loam in texture $\left(330 \mathrm{~g} \mathrm{~kg}^{-1}\right.$ sand, $360 \mathrm{~g} \mathrm{~kg}^{-1}$ silt, and $310 \mathrm{~g} \mathrm{~kg}^{-1}$ clay), with a $\mathrm{pH}$ of 8.2 and electrical conductivity of $1.6 \mathrm{dS} \mathrm{m}^{-1}$. The soil (top $20 \mathrm{~cm}$ ) contained $5 \mathrm{~g} \mathrm{~kg}^{-1}$ organic matter, $0.5 \mathrm{~g} \mathrm{~kg}^{-1}$ total $\mathrm{N}, 5.3 \mathrm{mg} \mathrm{kg}^{-1}$ Olsen-P, and $126 \mathrm{mg} \mathrm{kg}^{-1}$ available potassium.

\section{Experimental Details}

The influences of $\mathrm{N}$ fertilizer $\left(0,50,100\right.$, and $\left.150 \mathrm{~kg} \mathrm{~N} \mathrm{ha}^{-1}\right)$ and seeding rate $\left(400,600\right.$, and 800 seed $\left.\mathrm{m}^{-2}\right)$ on forage and grain yield of two barley cultivars (Fasih [FA] and CB 744 [CB]) in grain-only and dual-purpose systems (one forage removal before GS30) were investigated. The experiment was laid out in a split-split plot pattern based on a randomized complete block design with four replicates. Main plots, subplots, and sub-subplots were assigned to $\mathrm{N}$ fertilizer, seeding rate, and production system, respectively. Cultivar was not considered as an experimental factor, and statistical analysis was conducted separately for each cultivar. Fasih and $\mathrm{CB}$ are six-rowed feeding cultivars and are commonly cultivated in the region.

\section{Agronomy}

Chisel plow (to a depth of 20-25 cm) and light disking (two perpendicular rows) before planting were used for seedbed preparation. Individual plot size was $6 \mathrm{~m}$ by $3 \mathrm{~m}$. Both cultivars were planted on 8 Nov. 2009 and 15 Nov. 2010 at a soil depth of approximately $2.5 \mathrm{~cm}$ with $25-\mathrm{cm}$ row spacing using a seed drill 
with knife openers. All plots received equal irrigation, phosphorus fertilizer, and weed management. Irrigation was scheduled (8- to 10-d interval from late April to late May) to prevent water stress incidence (all plots received equal irrigation regardless of the treatments). Based on soil test results and current recommendation for barley production in the area, $200 \mathrm{~kg} \mathrm{ha}^{-1}$ triple superphosphate $\left(45 \% \mathrm{P}_{2} \mathrm{O}_{5}\right)$ was applied in a band $5 \mathrm{~cm}$ away from the planting rows before seeding. Nitrogen fertilizer (urea) was applied in two equal splits: at the time of planting (side-banded $8 \mathrm{~cm}$ from the seed) and after forage removal (as top dressing). Control plots $\left(\mathrm{N}_{0}\right)$ received no $\mathrm{N}$ fertilizer.

\section{Measurements}

Plants in the dual-purpose system were clipped before the development of the first hollow stem (at GS30) to minimize the likelihood of grain yield loss. In the grain-only plots, no forage clipping was undertaken. At forage removal, plants in an area of $3 \mathrm{~m}^{2}$ in respective plots were cut at a height of $5 \mathrm{~cm}$. After oven drying at $72^{\circ}$ for $48 \mathrm{~h}$, herbage dry yield was determined. To determine the influences of $\mathrm{N}$ and seeding rate on forage quality, a 200-g sample was taken and ground to pass through a $1-\mathrm{mm}$ sieve. Near-infrared spectroscopy (NIR) (Inframatic 8600, Perten Instruments) was used to determine forage quality indices, including crude protein (CP), dry matter digestibility (DMD), and acid detergent fiber (ADF). Before using NIR, forage quality indices of one replication (using three subsamples) of each treatment was determined using wet chemistry methods as described below. These were further used to calibrate NIR (Jafari et al., 2003).

Dry matter digestibility was measured according to the twostage fermentation technique of Tilley and Terry (1963), and ADF was determined using the procedure of Goering and Van Soest (1970). To determine CP, N content was measured according to the Kjeldahl method and then multiplied by 6.25 (AOAC, 1999).

Grains were considered to be mature at GS92 (Zadoks et al. 1974). In the grain-only system, plants were harvested on 25 June 2010 and 29 June 2011; harvest was delayed for a few days in the dual-purpose plots. At harvesting, plants in an area of $3 \mathrm{~m}^{2}$ from central rows of each plot were hand harvested at a height of $5 \mathrm{~cm}$. Biological yield (grain + straw weight) and grain yield (adjusted to $13 \%$ moisture content) was determined. Harvest index (HI) was calculated as the ratio of grain yield $\left(\mathrm{kg} \mathrm{ha}^{-1}\right)$ to biological yield at harvesting $\left(\mathrm{kg} \mathrm{ha}^{-1}\right)$. Total biomass production (forage yield + biological yield at harvesting) was also calculated. Crude protein of grain was determined following the Kjeldahl method.

\section{Statistical Analysis}

Data were subjected to ANOVA using PROC GLM of SAS by defining proper error terms for a split-split plot design in the model. Contrast statements (orthogonal contrasts) were used to test for linear, quadratic, and cubic responses of traits to $\mathrm{N}$ fertilizer, whereas linear and quadratic responses were tested for seeding rate. Regression lines were determined using PROC REG of SAS. When appropriate, mean comparison was implemented using a LSD test at $P \leq 0.05$. Because the ranking of treatments was fairly stable over the years, we ignored the interaction of year by experimental treatments and reported the results pooled over $2 \mathrm{yr}$.
Table I. Levels of significance for the effect of year, nitrogen rate $\left(0,50,100,150 \mathrm{~kg} \mathrm{ha}^{-1}\right)$, and seeding rate $(400,600$, and 800 seed $\mathrm{m}^{-2}$ ) on forage yield of two barley cultivars in a dualpurpose system.

\begin{tabular}{|c|c|c|c|}
\hline \multirow[b]{2}{*}{ Source of variation } & \multirow[b]{2}{*}{$d f$} & \multicolumn{2}{|c|}{ Barley cultivar $\nmid$} \\
\hline & & FA & $\mathrm{CB}$ \\
\hline Year & I & $* *$ & $* *$ \\
\hline Block (year) & 6 & - & - \\
\hline $\mathrm{N}$ rate & 3 & $* *$ & $* *$ \\
\hline Linear & I & * & ** \\
\hline Quadratic & 1 & nsł & ns \\
\hline Cubic & I & ns & ns \\
\hline Year $\times \mathrm{N}$ rate & 3 & $* *$ & $* *$ \\
\hline Year $\times$ block $(\mathrm{N}$ rate $)$ & 18 & - & - \\
\hline Seeding rate & 2 & $* *$ & $* *$ \\
\hline Linear & 1 & $* *$ & $* *$ \\
\hline Quadratic & I & ns & ** \\
\hline Year $\times$ seeding rate & 2 & ns & $*$ \\
\hline $\mathrm{N}$ rate $\times$ seeding rate & 6 & $* *$ & $* *$ \\
\hline Year $\times N$ rate $\times$ seeding rate & 6 & $* *$ & ** \\
\hline Residual & 48 & - & - \\
\hline
\end{tabular}

* Significant at the 0.05 probability level.

** Significant at the 0.01 probability level.

† CB, CB 744; FA, Fasih.

$\ddagger$ Not significant at $P \leq 0.05$.

\section{Economic Analysis}

The economic incentives of grain-only and dual-purpose systems were evaluated by investigating net returns of each system. Barley production cost (i.e., tillage, seed and seeding, fertilization, weed management, irrigation, forage removal in dual-purpose system, and grain harvest) were determined for each production system based on local market information. Barley grain and forage market prices were obtained from the local traders to calculate each system's gross return. Accordingly, production cost, gross income, and net return of each production system were determined.

\section{RESULTS}

\section{Forage Yield and Quality}

Analysis of variance showed significant effects of $\mathrm{N}$, seeding rate, and their interaction on forage yield of two barley cultivars (Table 1). Averaged over $2 \mathrm{yr}$ and experimental treatments, forage yields of FA and CB in a dual-purpose system were 2716 and $2260 \mathrm{~kg} \mathrm{ha}^{-1}$, respectively. Response of forage yield to $\mathrm{N}$ rate $\left(0-150 \mathrm{~kg} \mathrm{ha}^{-1}\right)$ was linear in both cultivars and was highly dependent on seeding rate. The forage yield response to $\mathrm{N}$ fertilizer was most notable at the lowest planting density $\left(\mathrm{P}_{400}\right.$; i.e., 400 seeds planted per $\mathrm{m}^{2}$ ), which was common to both cultivars (Fig. $2 \mathrm{a}$ and $2 \mathrm{~b}$ ). At higher seeding rates, the response of forage yield to $\mathrm{N}$ was less pronounced, especially in FA. Averaged over years and seeding rates, increasing the $\mathrm{N}$ rate from 0 to $150 \mathrm{~kg} \mathrm{ha}^{-1}$ improved forage yield of CB by $32 \%\left(2546 \mathrm{~kg} \mathrm{ha}^{-1}\right)$ compared with unfertilized controls $\left(1916 \mathrm{~kg} \mathrm{ha}^{-1}\right)$; this increase was $9 \%$ in FA.

According to the ANOVA results, barley forage quality indices, including CP, DMD, and ADF, were not influenced by $\mathrm{N}$, seeding rate, and their interaction. Vegetative forage of $\mathrm{CB}$ contained $283 \mathrm{~g} \mathrm{~kg}^{-1} \mathrm{CP}, 319 \mathrm{~g} \mathrm{~kg}^{-1} \mathrm{ADF}$, and $605 \mathrm{~g} \mathrm{~kg}^{-1} \mathrm{DMD}$. These values in FA were 268, 273, and $639 \mathrm{~g} \mathrm{~kg}^{-1}$ for CP, ADF, and DMD, respectively. 
Table 2. Levels of significance for the effect of year, nitrogen rate $\left(0,50,100,150 \mathrm{~kg} \mathrm{ha}^{-1}\right)$, seeding rate $\left(400,600\right.$, and $\left.800 \mathrm{seed} \mathrm{m}^{-2}\right)$, and production system (grain-only and dual-purpose system) on grain yield, harvest index, and total biomass of two barley cultivars.

\begin{tabular}{|c|c|c|c|c|c|c|c|}
\hline \multirow[b]{2}{*}{ Source } & \multirow[b]{2}{*}{$d f$} & \multicolumn{2}{|c|}{ Grain yield } & \multicolumn{2}{|c|}{ Harvest index } & \multicolumn{2}{|c|}{ Total biomass $\dagger$} \\
\hline & & FA $\ddagger$ & $\mathrm{CB} \oint$ & FA & CB & FA & $\mathrm{CB}$ \\
\hline Year & 1 & $*$ & $* *$ & $* *$ & $*$ & $* *$ & $* *$ \\
\hline Block (year) & 6 & $-\mathbb{T}$ & - & - & - & - & - \\
\hline $\mathrm{N}$ rate & 3 & ns\# & $* *$ & ns & $* *$ & ** & $* *$ \\
\hline Linear & 1 & ns & $* *$ & $* *$ & $* *$ & ns & ns \\
\hline Quadratic & I & ns & ns & ns & ns & ns & ns \\
\hline Cubic & 1 & ns & ns & ns & ns & ns & ns \\
\hline Year $\times N$ rate & 3 & $* *$ & $* *$ & $* *$ & $* *$ & $* *$ & $* *$ \\
\hline Year $\times$ block $(\mathrm{N}$ rate $)$ & 18 & - & - & - & - & - & - \\
\hline Seeding rate & 2 & $* *$ & $* *$ & $* *$ & $* *$ & $* *$ & $* *$ \\
\hline Linear & I & $* *$ & $* *$ & $* *$ & $* *$ & $* *$ & ns \\
\hline Quadratic & 1 & $* *$ & $* *$ & ns & ns & $* *$ & $* *$ \\
\hline Year $\times$ seeding rate & 2 & $* *$ & $* *$ & $* *$ & $* *$ & ns & $* *$ \\
\hline $\mathrm{N}$ rate $\times$ seeding rate & 6 & $* *$ & $* *$ & $* *$ & $* *$ & $* *$ & $* *$ \\
\hline $\begin{array}{l}\text { Year } \times N \text { rate } \times \text { seeding } \\
\text { rate }\end{array}$ & 6 & $* *$ & $*$ & $* *$ & $* *$ & $* *$ & $* *$ \\
\hline $\begin{array}{l}\text { Year } \times N \text { rate } \times \text { block } \\
\text { (seeding rate) }\end{array}$ & 48 & - & - & - & - & - & - \\
\hline Production system & 1 & $* *$ & $* *$ & $* *$ & $* *$ & $* *$ & $* *$ \\
\hline Year $\times$ production system & 1 & ns & $* *$ & $* *$ & $* *$ & ns & ns \\
\hline $\begin{array}{l}\mathrm{N} \text { rate } \times \text { production } \\
\text { system }\end{array}$ & 3 & $* *$ & ns & $*$ & ns & $* *$ & ns \\
\hline $\begin{array}{l}\text { Seeding rate } \times \text { production } \\
\text { system }\end{array}$ & 2 & $* *$ & $* *$ & ns & $* *$ & $*$ & $* *$ \\
\hline $\begin{array}{l}\text { Year } \times N \text { rate } \times \\
\text { production system }\end{array}$ & 3 & $*$ & $* *$ & $* *$ & $* *$ & $*$ & ns \\
\hline $\begin{array}{l}\text { Year } \times \text { seeding rate } \times \\
\text { production system }\end{array}$ & 2 & $* *$ & $* *$ & $* *$ & $*$ & $* *$ & ns \\
\hline $\begin{array}{l}N \text { rate } \times \text { seeding rate } \times \\
\text { production system }\end{array}$ & 6 & $* *$ & $* *$ & $* *$ & $* *$ & $* *$ & $* *$ \\
\hline $\begin{array}{l}\text { Year } \times N \text { rate } \times \text { seeding } \\
\text { rate } \times \text { production system }\end{array}$ & 6 & $*$ & $* *$ & $* *$ & $* *$ & $* *$ & $* *$ \\
\hline Residual & 72 & - & - & - & - & - & - \\
\hline
\end{tabular}

* Significant at the 0.05 probability level.

** Significant at the 0.01 probability level.

† Total biomass in grain-only system is biological yield at harvesting (grain + straw) and in dual-purpose system total biomass refers to biological yield at harvesting plus forage yield harvested at growth stage 30 .

$\ddagger$ Fasih.

$\S$ CB 744.

Tा Lines without stars are error terms.

\# Nonsignificant.
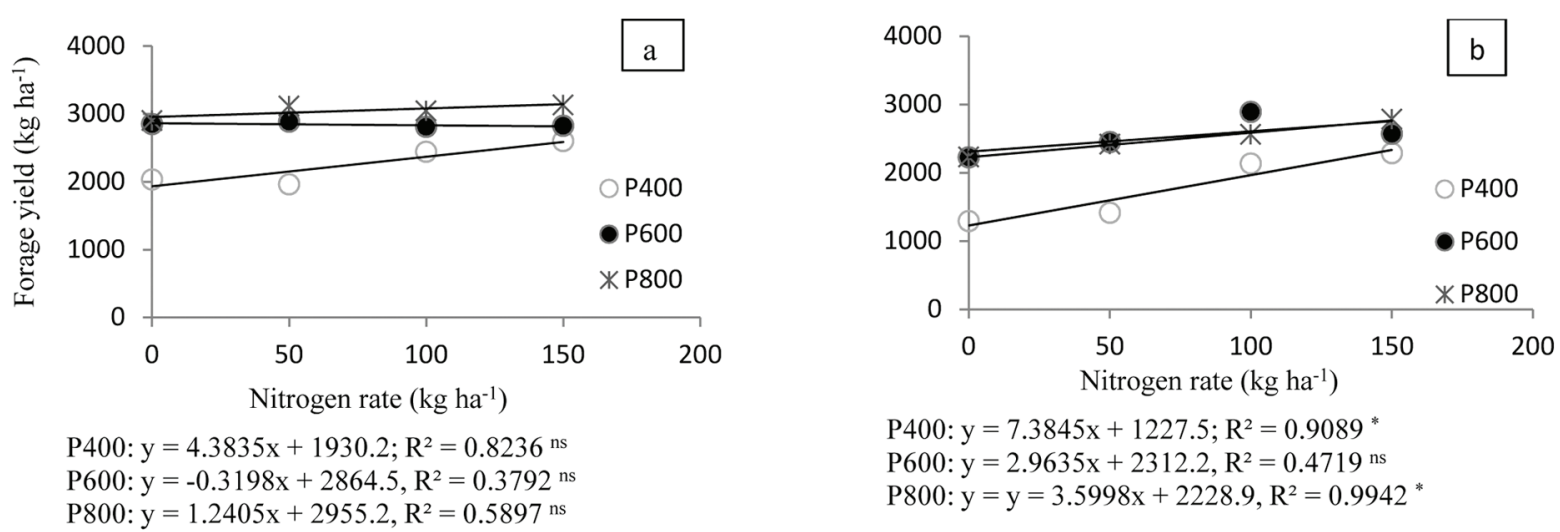

Fig. 2. Forage yield of FA (Fasih) and CB (CB 744) cultivars of barley in a dual-purpose system as influenced by seeding rate, $\mathrm{N}$ rate, and their interaction. 


\section{Grain Yield and Grain Protein Content}

Forage removal had a detrimental effect on grain yield of both cultivars: 24 and $26 \%$ yield penalties were observed for FA and $\mathrm{CB}$ in the dual-purpose system (Fig. 3a and 3b).

The effect of $\mathrm{N}$ fertilizer on grain yield differed between cultivars and production systems (Table 2). In the grain-only system, a linear regression with a slight slope was found between grain yield and $\mathrm{N}$ rate in FA $\left(R^{2}=0.97\right)($ Fig. $2 \mathrm{a})$ and $\mathrm{CB}\left(R^{2}=0.95\right)$ (Fig. 3b). Regression analysis showed a nonsignificant relation between grain yield and $\mathrm{N}$ rate in the dual-purpose system for both cultivars. Fasih grain yield remained stable among the $\mathrm{N}$ rates (Fig. 3a), whereas $\mathrm{CB}$ yield continued to slightly rise with the incremental $\mathrm{N}$ rate (Fig. $3 \mathrm{~b}$ ).

In both production systems, a significant quadratic relation was

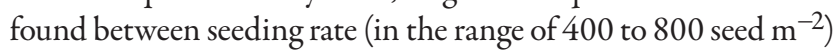
and grain yield, which was consistent for both cultivars (except $\mathrm{CB}$ yield in the dual-purpose system) (Fig. $4 \mathrm{a}$ and $4 \mathrm{~b}$ ). Increasing seeding rate from $\mathrm{P}_{400}$ to $\mathrm{P}_{600}$ enhanced $\mathrm{FA}$ and $\mathrm{CB}$ grain yield by 60 and $58 \%$ in the grain-only system and by 61 and $7 \%$ in the dual-purpose system. An additional increase from 600 to 800 seeds $\mathrm{m}^{-2}$ adversely affected grain yield of both crops regardless of the production system. Statistical analysis indicated that

\section{FA}
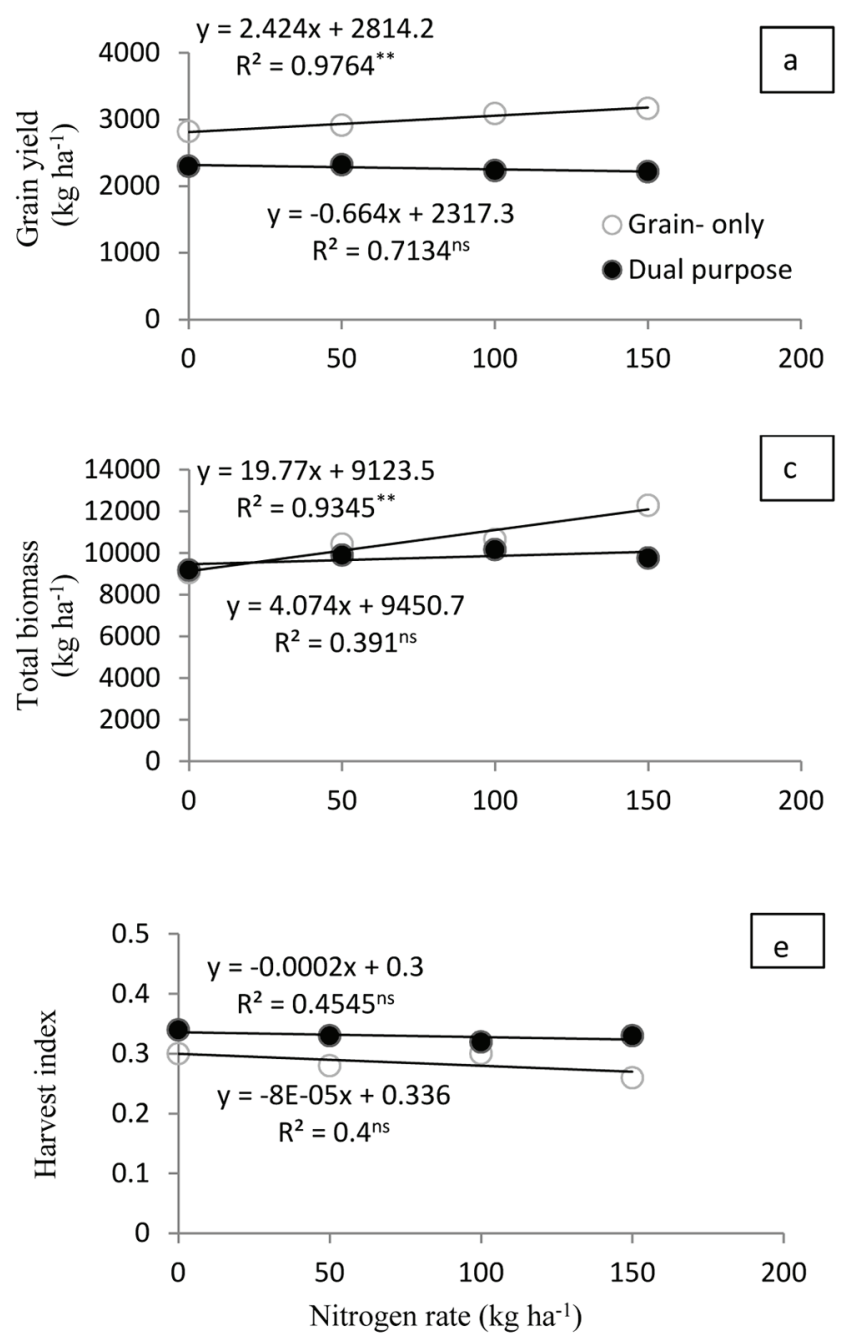

the interaction effect of seeding rate $\times \mathrm{N}$ rate on barley grain yield was also significant (Table 2), showing that the seeding rate played an important role in the response of barley to $\mathrm{N}$ rate. When barley was planted at a lower seeding rate $\left(\mathrm{P}_{400}\right)$, grain yield positively responded to $\mathrm{N}$ fertilizer (Fig. $5 \mathrm{a}$ and $\mathrm{5b}$ ). As the seeding rate increased, however, yield response to $\mathrm{N}$ was hindered. The results indicated that application of higher rates of $\mathrm{N}$ did not result in grain yield advantages of dual-purpose barley. Regardless of the production system, 600 seed m $\mathrm{m}^{-2}$ and $100 \mathrm{~kg} \mathrm{~N} \mathrm{ha}^{-1}$ were found to be the optimum seeding and $\mathrm{N}$ rates for barley.

Averaged over all treatments, FA and CB grains contained 133 and $114 \mathrm{~g} \mathrm{~kg}^{-1} \mathrm{CP}$ (Fig. 6). Grain $\mathrm{CP}$ was influenced by $\mathrm{N}$ rate but not by seeding rate. In both cultivars, $\mathrm{CP}$ was linearly correlated with $\mathrm{N}$ rate; a substantial increasing trend was observed as higher rate of $\mathrm{N}$ was applied (Fig. 6).

\section{Total Biomass and Harvest Index}

Forage removal had detrimental effects on total biomass production of FA and CB. Biomass of FA responded linearly to $\mathrm{N}$ rate in the grain-only system but not in the dual-purpose system (Fig. 3c). Regardless of the production system, no significant trend responses were found between biomass and $\mathrm{N}$ rate in $\mathrm{CB}$
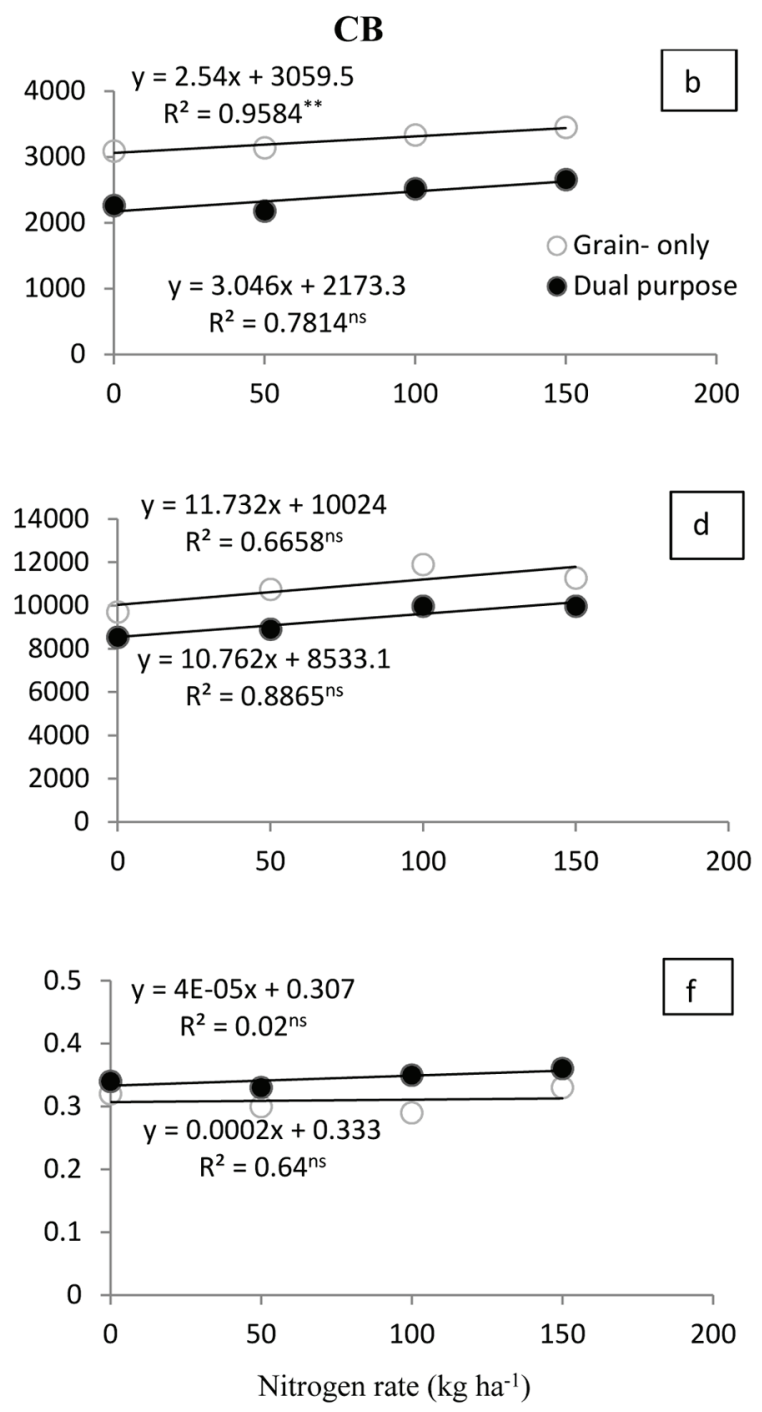

Fig. 3. Grain yield, total biomass production, and harvest index of FA (Fasih) and CB (CB 744) cultivars of barley in grain-only and dualpurpose systems as influenced by $\mathrm{N}$ rate. 

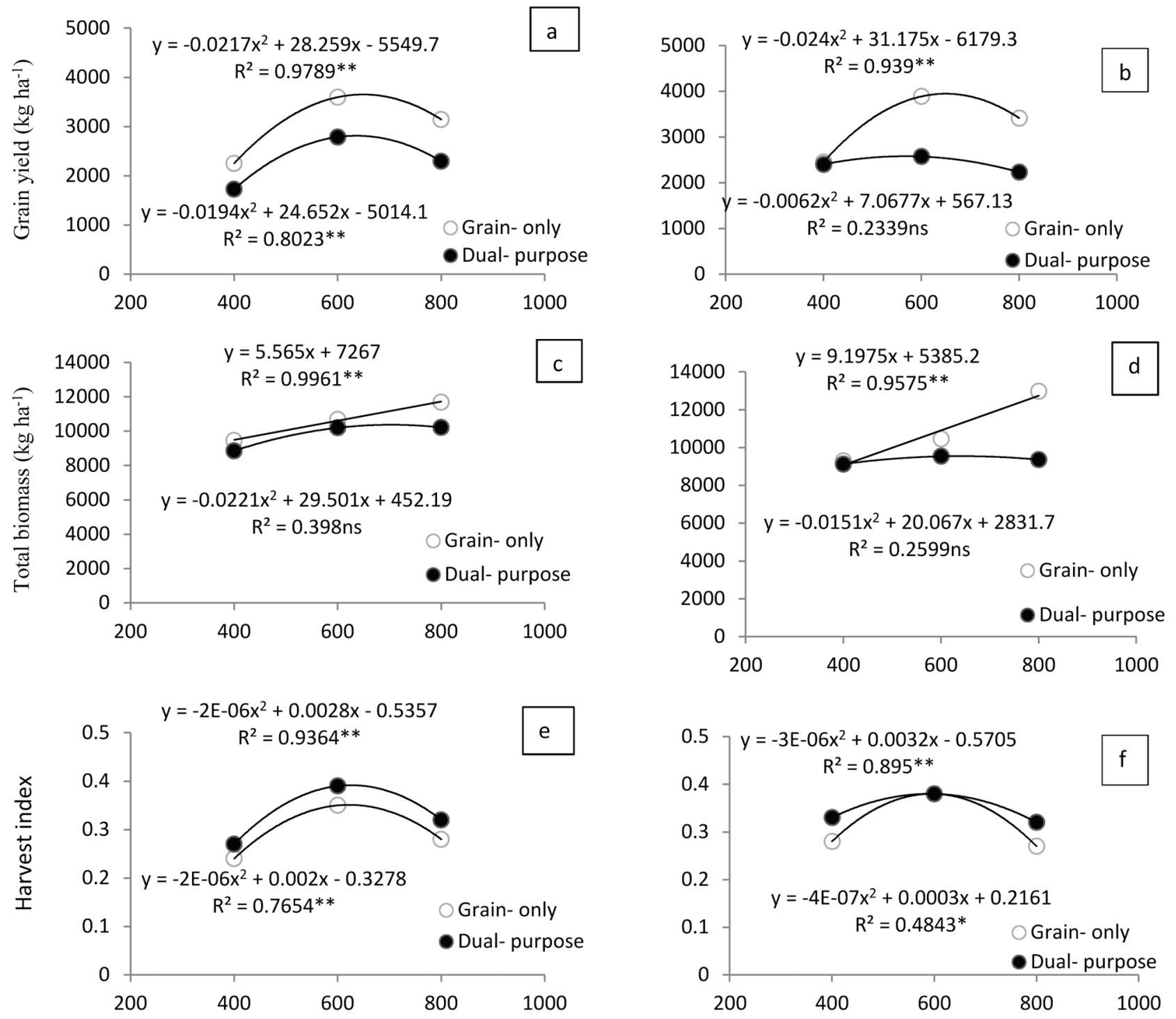

Fig. 4. Grain yield, total biomass production, and harvest index of FA (Fasih) and CB (CB 744) cultivars of barley in grain-only and dualpurpose systems as influenced by seeding rate.

(Fig. 3d). In the grain-only system, biomass continued to rise with the incremental seeding rate, and the maximal biomass of both cultivars was obtained at $\mathrm{P}_{800}$ (Fig. $4 \mathrm{c}$ and $4 \mathrm{~d}$ ). In the dual-purpose system, however, biomass amounts obtained from $\mathrm{P}_{600}$ and $\mathrm{P}_{800}$ were not statistically different. The combination of high levels of $\mathrm{N}$ and seeding rate maximized biomass production of both barley cultivars, especially in the grain-only system (Fig. 5c and 5d).

Despite the lower grain yield and total biomass production in the dual-purpose system, HI in this system was greater than that in grain-only system by 13 and $9 \%$ for FA and CB, respectively. This was due to the greater influence of forage removal on biomass compared with its negative effect on grain yield. Harvest index in barley cultivars was not influenced by $\mathrm{N}$ application (Fig. 3e and 3f). The response of HI to rising seeding rate was quadratic: increasing seeding rates from 400 to 600 seed $^{-2}$ improved HI, but further increments decreased HI (Fig. 4e and 4f).

\section{Economic Return}

Details of the economic analysis are given in Table 3. Using the actual prices obtained from local markets, barley forage

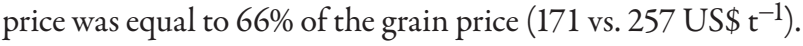
Defoliation in dual-purpose systems was associated with approximately $25 \%$ grain yield penalty. In this system, however, 2716 and $2260 \mathrm{~kg} \mathrm{ha}^{-1}$ dry forage were produced from FA and CB. Economic analysis showed that the extra income from forage harvested in late winter was sufficient to counterbalance grain yield penalty in this system. Accordingly, net returns obtained from FA and CB in the dual-purpose system were $\$ 271 \mathrm{ha}^{-1}$ (44\%) and $\$ 164 \mathrm{ha}^{-1}(24 \%)$, respectively, greater than that obtained in the grain-only system (Table 3 ).

\section{DISCUSSION}

Late winter and early spring are considered as the feed gap period in many areas of Iran. During this time, the market price of forage and hay are considerably high. Clipping fall-sown cereals is a potential source of good-quality forage for the feed gap 

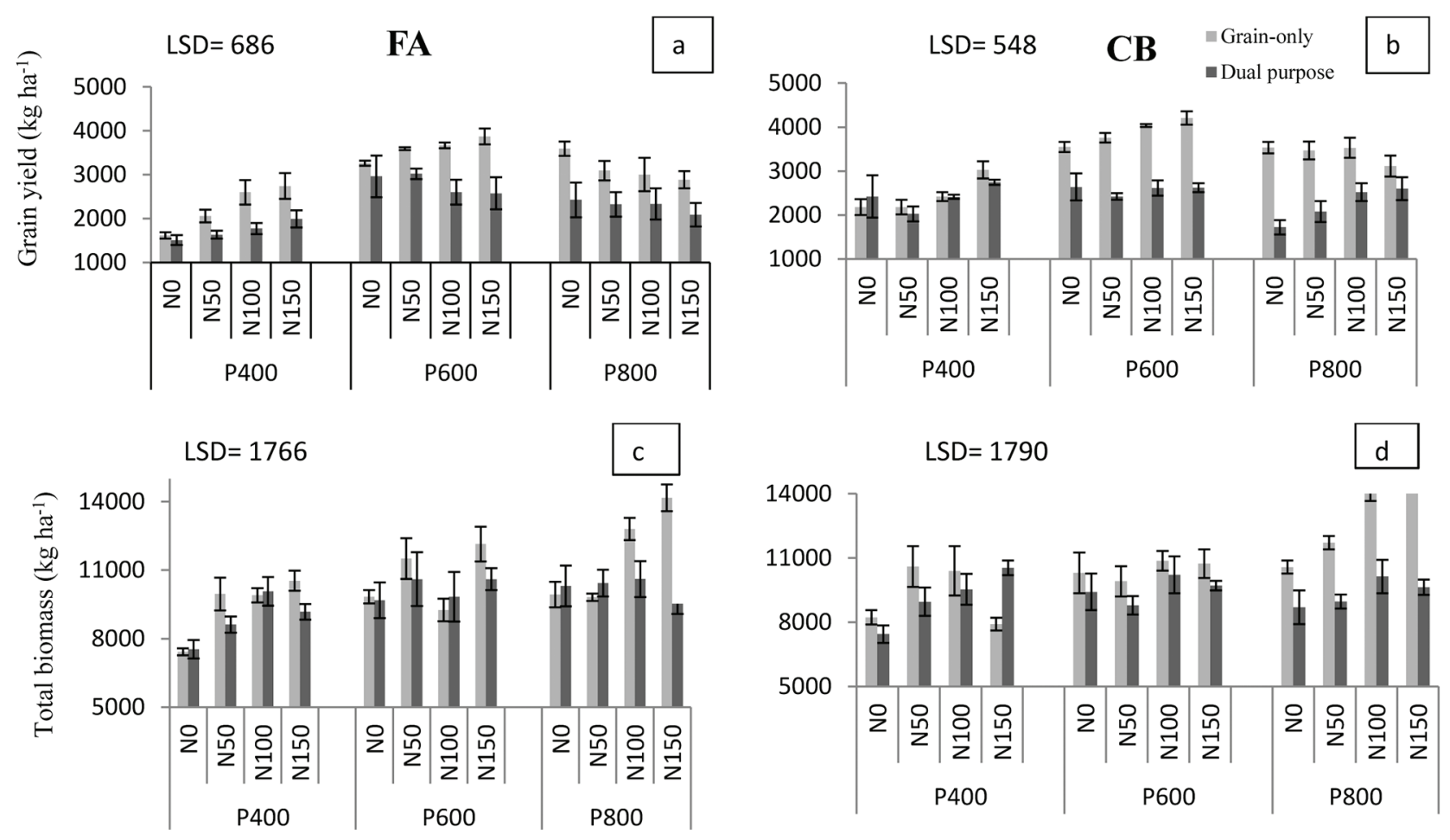

Fig. 5. Grain yield and biomass production of FA (Fasih) and CB (CB 744) cultivars of barley as influenced by $\mathrm{N}$ rate, seeding rate, and production system. Vertical bars show SE $(n=8)$.

period. However, widespread adoption of a dual-purpose system depends on sufficient economic incentives of the systems. The results of the current study showed that 2716 and $2260 \mathrm{~kg} \mathrm{ha}^{-1}$ dry herbage can be produced by FA and CB, containing 268 and $283 \mathrm{~g} \mathrm{~kg}^{-1} \mathrm{CP}$, respectively. Despite the $25 \%$ grain yield penalty from forage removal in dual-purpose systems, economic analysis revealed considerably higher revenue in this system. The greater feasibility of dual-purpose systems compared with grain-only systems has been noted (Arzadun et al., 2003, 2006; Decker et al., 2009). Arzadun et al. (2006) evaluated the increase of beef weight versus the decrease of wheat grain yield at increasing grazing pressures in a dual-purpose system and concluded that increased grazing pressure (grazing height from 7 to $3 \mathrm{~cm}$ ) was profitable for farmers. Perhaps the adoption of an appropriate dual-purpose system simplifies crop-livestock integration in this region, which will have economic and ecological advantages, such as (i) implementation of a dual-purpose system can enhance a system's profitability, which is extremely important, especially in rural areas, and (ii) the successful use of dual-purpose systems contributes to environmental protection because it prevents

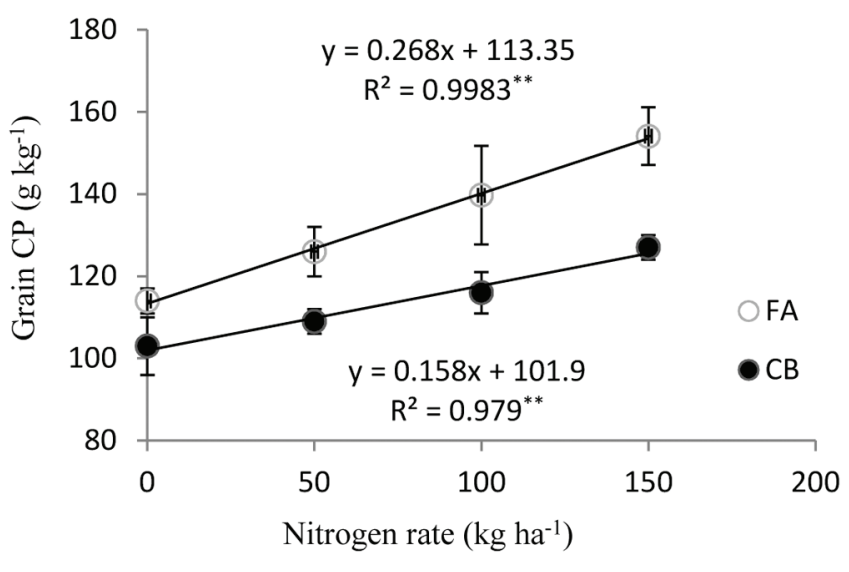

Fig. 6. Trend response of grain protein content of FA (Fasih) and $\mathrm{CB}$ (CB 744) cultivars of barley to $\mathrm{N}$ rate. Vertical bars show $\mathrm{SE}$ $(n=24)$.

Table 3. Details of production costs and incomes in grain-only and dual-purpose barley. Price of barley forage and grain was considered as I7I and 257 US\$ $\mathrm{t}^{-1}$.

\begin{tabular}{|c|c|c|c|c|c|}
\hline Production system & Production cost $\dagger$ & Forage income & Grain income & Gross income & Net income \\
\hline & & & - US\$ ha-1 & & \\
\hline \multicolumn{6}{|l|}{ Fasih } \\
\hline Grain-only & 149 & 0 & 770 & 770 & 621 \\
\hline Dual-purpose & 157 & 466 & 583 & 1049 & 892 \\
\hline \multicolumn{6}{|l|}{ CB 744} \\
\hline Grain-only & 149 & 0 & 836 & 836 & 686 \\
\hline Dual-purpose & 157 & 389 & 618 & 1007 & 850 \\
\hline
\end{tabular}

† Production cost and returns are averaged over nitrogen treatments and seeding rates studied in this article. Higher production cost in the dualpurpose system is related to the cost of forage removal at growth stage 30 . 
overgrazing of rangelands, an important cause of land degradation and desertification in arid and semiarid regions of the country (NAP, 2005). These advantages offer opportunities toward a more sustainable farming system in this semiarid environment.

Barley forage removal was associated with 24 and 26\% grain yield penalties in FA and CB, respectively. This degree of grain yield loss is within the range reported for wheat and barley in dual-purpose systems elsewhere (Epplin et al., 2000; Virgona et al., 2006). Francia et al. (2006) reported a $13.5 \%$ grain yield reduction for barley after forage removal in southern Italy. Higher degrees of reduction have also been reported (Dann et al., 1983; Pumphrey, 1970). As reviewed by Harrison et al. (2012), postdefoliation yield reduction may happen due to several factors, such as frost damage after defoliation, poor leaf area development, delayed maturation, increased rates of green area senescence, and decreased grain filling period. The barley cultivars used in the current study are improved for grain-only purposes. The rate of leaf area recovery after defoliation in these cultivars may not be sufficient. This can in part explain over $25 \%$ grain yield reduction after defoliation in this study. Moreover, maturation in dual-purpose plots occurred a few days later than in grain-only plots, which may increase the chance of temperature stress around anthesis and the grain filling period. This is why plants in grain-only systems are more likely to escape damage from hot winds, drought, and rust, which normally are experienced during later growing stages of wheat and barley in this region. Other researchers have found similar results about delaying in phenological development of cereals as a consequence of forage removal (Royo et al., 1997; Tian et al., 2012; Virgona et al., 2006). The extent of delay in crop phenology was dependent on the time of forage removal; cutting or grazing before stem elongation (GS30) resulted in only small delays (0-5 d) in crop phenology (Tian et al., 2012; Virgona et al., 2006), whereas defoliation at later growth stages resulted in greater delays (Royo et al., 1997).

Because defoliation removes accumulated $\mathrm{N}$ in plant aerial parts, application of extra $\mathrm{N}$ is a common practice in the targeted areas where dual-purpose systems are practiced. However, the results of the present study showed that no extra $\mathrm{N}$ fertilizer is required for barley in dual-purpose systems beyond the amount that is usually used in grain-only systems. Our data revealed insignificant differences between forage and grain yield at $\mathrm{N}$ fertilization rates of 100 and $150 \mathrm{~kg} \mathrm{ha}^{-1}$, which reflect the lower $\mathrm{N}$ use efficiency at $150 \mathrm{~kg} \mathrm{ha}^{-1}$. Therefore, $100 \mathrm{~kg} \mathrm{ha}^{-1}$ could be considered as the optimum rate of $\mathrm{N}$ fertilizer for barley production in both production systems. The positive impact of $\mathrm{N}$ on barley yield, especially on forage production in dual-purpose systems, is consistent with previous reports (Khalil et al., 2011; Pandey, 2005).

In this study, $\mathrm{N}$ fertilizer was more effective at improving forage production and grain yield when planting density was low. The best response to $\mathrm{N}$ fertilization was associated with $\mathrm{P}_{600}$, indicating that lower or higher seeding rates beyond the optimum range decreased efficiency in the utilization of $\mathrm{N}$ fertilizer. At the lowest planting density $\left(\mathrm{P}_{400}\right)$, betweenplant competition was low in response to the application of $\mathrm{N}$ fertilizer, where higher rates of $\mathrm{N}$ stimulated tillering and increased forage yield. However, due to low plant population and despite more tillers per plant, resources (i.e., nutrients, moisture, light, etc.), have not been fully utilized when plant density was low. As seeding rate increased, a greater potential to use the resources was created, which resulted in higher forage yield; however, due to greater competition between plants, especially at the highest planting density $\left(800\right.$ seed $\left.\mathrm{m}^{-2}\right)$, the forage yield did not respond to $\mathrm{N}$ application. In other words, when seeding rate was doubled (from 400 to $800 \mathrm{seed} \mathrm{m}^{-2}$ ), no unoccupied spaces remained for plants to respond to $\mathrm{N}$ fertilizer. Combining high planting density with high levels of $\mathrm{N}\left(\mathrm{P}_{800}+150 \mathrm{~kg} \mathrm{~N} \mathrm{ha}^{-1}\right)$ had detrimental effects on grain production, although it was alleviated by forage removal in the dual-purpose system, especially for CB. This could be attributed to lower incidence of lodging in dual-purpose systems as a consequence of forage removal (Winter et al., 1990).

In the current study, altering seeding rate from 400 to 800 seed $\mathrm{m}^{-2}$ significantly influenced barley grain yield. A quadratic function effectively described grain yield response to seeding rate (except for CB in dual-purpose system), which is consistent with reports by other researchers (Geleta et al., 2002; Lloveras et al., 2004). In contrast, some other researchers have reported little or no effects of barley seeding rate on yield, especially at rates above 200 seeds $\mathrm{m}^{-2}$ (McKenzie et al., 2005; O’Donovan et al., 2008). Variation among the genotypes (especially in tillering capacity) may explain these differences. The highest grain yield of both barley cultivars in the current study was obtained from $\mathrm{P}_{600}$, and additional increases in planting density from $\mathrm{P}_{600}$ to $\mathrm{P}_{800}$ reduced grain yield. Seeding rate highly influences the relative importance of within-plant and between-plant competition (Tompkins et al., 1991), emphasizing that 600 seed $\mathrm{m}^{-2}$ is the optimum seeding rate for barley production in both grain-only and dual-purpose systems. No extra seed is required in dual-purpose systems than what is usually used in grain-only system.

\section{CONCLUSION}

Despite the grain yield penalty in the dual-purpose system, this system was economically feasible due to the good price of forages during late winter and early spring in the region. A seeding rate of 600 seed $\mathrm{m}^{-2}$ and a $\mathrm{N}$ fertilization rate $100 \mathrm{~kg} \mathrm{~N} \mathrm{ha}^{-1}$ were found to be optimum for barley production in grain-only and dual-purpose systems.

\section{REFERENCES}

Afshar, R.K., M. Ansari Jovini, M.R. Chaichi, and M. Hashemi. 2014. Grain sorghum response to arbuscular mycorrhiza and phosphorus fertilizer under deficit irrigation. Agron. J. 106:1212-1218. doi:10.2134/agronj13.0589

Afshar, R.K., M.R. Chaichi, H. Moghadam, and S.M.R. Ehteshami. 2012. Irrigation, phosphorus fertilizer and phosphorus solubilizing microorganism effects on yield and forage quality of turnip (Brassica rapa L.) in an arid region of Iran. Agric. Res. 1:370-378. doi:10.1007/s40003-012-0039-1

Arzadun, M.J., J.I. Arroquy, H.E. Laborde, and R.E. Brevedan. 2006. Effect of planting date, clipping height, and cultivar on forage and grain yield of winter wheat in Argentinean Pampas. Agron. J. 98:1274-1279. doi:10.2134/agronj2005.0313

Arzadun, M.J., J.I. Arroquy, H.E. Laborde, and R.E. Brevedan. 2003. Grazing pressure on beef and grain production of dual-purpose wheat in Argentina. Agron. J. 95:1157-1162. doi:10.2134/ agronj2003.1157

Association of Official Analytical Chemists (AOAC). 1999. Official methods of analysis, 16th ed. AOAC, Washington, DC. 
Dann, P.R., A. Axelsen, B.S. Dear, E.R. Williams, and C.B.H. Edwards. 1983. Herbage, grain and animal production from winter-grazed cereal crops. Aust. J. Exp. Agric. 23:154-161. doi:10.1071/ EA9830154

Decker,J.E., F.M.Epplin, D.L. Morley, and T.F. Peeper. 2009. Economics of five wheat production systems with no-till and conventional tillage. Agron. J. 101:364-372. doi:10.2134/agronj2008.0159

Edwards, J.T., B.F. Carver, G.W. Horn, and M.E. Payton. 2011. Impact of dual-purpose management on wheat grain yield. Crop Science 51:2181-2185. doi:10.2135/cropsci2011.01.0043

Epplin, F.M., I. Hossain, and E.G. Krenzer, Jr. 2000. Winter wheat fall-winter forage yield and grain yield response to planting date in a dual-purpose system. Agric. Syst. 63:161-173. doi:10.1016/ S0308-521X(00)00004-4

Francia, E., N. Pecchioni, O. Li Destri Nicosia, G. Paoletta, L. Taibi, V. Franco, M. Odoardi, A.M. Stanca, and G. Delogu. 2006. Dualpurpose barley and oat in a Mediterranean environment. Field Crops Res. 99:158-166. doi:10.1016/j.fcr.2006.04.006

Geleta, B., M. Atak, P.S. Baenziger, L.A. Nelson, D.D. Baltenesperger, K.M. Eskridge, and D.R. Shelton. 2002. Seeding rate and genotype effect on agronomic performance and end-use quality of winter wheat. Crop Sci. 42:827-832. doi:10.2135/cropsci2002.0827

Goering, H.K., and P.J. Van Soest. 1970. Forage fiber analysis: Apparatus reagents, procedures, and some applications. Agriculture handbook 379. US Gov. Print. Office, Washington, DC

Hadjichristodoulou, A. 1991. Dual-purpose barley. Rachis 10:13-16.

Harrison, M.T., J.R. Evans, H. Dove, and A.D. Moore. 2012. Dualpurpose cereals: Can the relative influences of management and environment on crop recovery and grain yield be dissected? Crop Pasture Sci. 62:930-946. doi:10.1071/CP11066

Hossain, I., F.M. Epplin, and E.G. Krenzer. 2003. Planting date influence on dual-purpose winter wheat forage yield, grain yield, and test weight. Agron. J. 95:1179-1188. doi:10.2134/agronj2003.1179

Jafari, A., V. Connolly, A. Frolich, and E.J. Walsh. 2003. A note on estimation of quality parameters in perennial ryegrass by near infrared reflectance spectroscopy. Ir. J. Agric. Food Res. 42:293-299.

Khalil, S.K., F. Khan, A. Rehman, F.I.D.A. Muhammad, A.K. Amanullah, S.W. Khan, and H. Khan. 2011. Dual-purpose wheat for forage and grain yield in response to cutting, seed rate and nitrogen. Pak. J. Bot. 43:937-947.

Ladha, J.K., H. Pathak, T.J. Krupnik, J. Six, and C. Van Kessel. 2005. Efficiency of fertilizer nitrogen in cereal production: Retrospects and prospects. Adv. Agron. 87:85-156. doi:10.1016/ S0065-2113(05)87003-8

Lloveras, J., J. Manent, J. Viudas, A. López, and P. Santiveri. 2004. Seeding rate influence on yield and yield components of irrigated winter wheat in a Mediterranean climate. Agron. J. 96:1258-1265. doi:10.2134/agronj2004.1258
McKenzie, R.H., A.B. Middleton, and E. Bremer. 2005. Fertilization, seeding date and seeding rate for malting barley yield and quality in southern Alberta. Can. J. Plant Sci. 85:603-614. doi:10.4141/ P04-152

NAP. 2005. National action program to combat desertification and mitigate the effects of drought of Islamic Republic of Iran. The Forest, Rangeland and Watershed Management Organization, Tehran, Iran.

O’Donovan, J.T., G.W. Clayton, C.A. Grant, K.N. Harker, T.K. Turkington, and N.Z. Lupwayi. 2008. Effect of nitrogen rate and placement and seeding rate on barley productivity and wild oat fecundity in a zero tillage system. Crop Sci. 48:1569-1574. doi: $10.2135 /$ cropsci2007.10.0587

Pandey, A.K. 2005. Effect of agronomic practices on green fodder, grain yield and economics of dual-purpose wheat (Triticum aestivum). Indian J. Agr. Sci. 75:27-29.

Pumphrey, F.V. 1970. Semi dwarf winter wheat response to early spring clipping and grazing. Agron. J. 62:641-643. doi:10.2134/agronj19 $70.00021962006200050028 x$

Royo, C., A. Lopez, J. Serra, and F. Tribo. 1997. Effect of sowing date and cutting stage on yield and quality of irrigated barley and triticale used for forage and grain. J. Agron. Crop Sci. 179:227234. doi:10.1111/j.1439-037X.1997.tb00521.x

Sadeghpour, A., E. Jahanzad, A. Esmaeili, M.B. Hosseini, and M. Hashemi. 2013. Forage yield, quality and economic benefit of intercropped barley and annual medic in semi-arid conditions: Additive series. Field Crops Res. 148:43-48. doi:10.1016/j. fcr.2013.03.021

Sij, J., M. Belew, and W. Pinchak. 2011. Nitrogen management in no-till and conventional till dual-use wheat/stocker systems. Tex. J. Agric. Nat. Resour. 24:38-49.

Tian, L.H., L.W. Bell, Y.Y. Shen, and J.P.M. Whish. 2012. Dual-purpose use of winter wheat in western China: Cutting time and nitrogen application effects on phenology forage production, and grain yield. Crop Pasture Sci. 63:520-528. doi:10.1071/CP12101

Tilley, J.M., and R.A. Terry. 1963. A two-stage technique for the in vitro digestion of forage crops. J. British Grassland 18:104-111.

Tompkins, D.K., G.E. Hultgreen, A.T. Wright, and D.B. Fowler. 1991. Seed rate and row spacing of no-till winter wheat. Agron. J. 83:684-689. doi:10.2134/agronj1991.00021962008300040007x

Virgona, J.M., F.A.J. Gummer, and J.F. Angus. 2006. Effects of grazing on wheat growth, yield, development, water use, and nitrogen use. Aust. J. Agric. Res. 57:1307-1319. doi:10.1071/AR06085

Winter, S.R., E.K. Thompson, and J.T. Musick. 1990. Grazing winter wheat: II. Height effects on response to production system. Agron. J. 82:37-41. doi:10.2134/agronj1990.00021962008200010008x

Zadoks, J.C., T.T. Chang, and C.F. Konzak. 1974. A decimal code for the growth stages of cereals. Weed Res. 14:415-421. doi:10.1111/j.1365-3180.1974.tb01084.x 